\title{
Challenges of Distance Education Assessment in the Health Professions during the COVID-19 Pandemic: A Philippine Reflection in the Rapid Review of International Context
}

\author{
Carl Joseph Ablao, RND, MHPEd, 1,2 Dan Clarence Diaz, RRT, MHPEd ${ }^{3}$ and Joshua Macapagal, DMD, MHPEd ${ }^{4}$ \\ ${ }^{1}$ Far Eastern University Institute of Education, Manila, Philippines \\ ${ }^{2}$ The Graduate School, University of Santo Tomas, Manila, Philippines \\ ${ }^{3} \mathrm{De}$ La Salle Medical and Health Sciences Institute College of Medical Imaging and Therapy, Dasmarinas City, Cavite, Philippines \\ ${ }^{4}$ Centro Escolar University School of Dentistry, Manila, Philippines
}

\begin{abstract}
Objective. Assessment in distance education provides a safe evaluation environment during the COVID-19 pandemic. The purpose of this study is to explore the extent of knowledge available regarding the challenges of assessment in distance education of health professions during the 2020-2021 COVID-19 pandemic and to discuss a reflection in the Philippine setting.
\end{abstract}

Method. We conducted a rapid review through an electronic search in PubMed, Scopus, CINAHL, ERIC, Web of Science, and PsycINFO databases.

Results. Out of 1,519 articles, 9 were included for analysis. Philippine reflection was provided through an unsystematic search of literature. Challenges in assessment included resources, learners' issues, technical issues of the learning management system, and methodological assessment issues. Distance education allowed instructors to safely continue delivery of instruction and assessment during the pandemic.

Conclusion. The Philippine setting is relatable to the current international context of the challenges of assessment in distance education in health professions.

Keywords: assessment, challenges, distance education, health professions

\section{INTRODUCTION}

The COVID-19 pandemic has made a huge impact on the lives of many people worldwide. One aspect that has been greatly affected by the pandemic is the educational system. ${ }^{1}$ The educational system during the COVID-19 pandemic has made a remarkable shift from the traditional face-to-face method to emergency remote learning., ${ }^{2,3}$ Emergency remote learning is a shift to a fully remote instructional structure during a crisis. The pandemic converted the usual set-up of having classes within the four corners of the classroom to virtual classes through online platforms, in compliance with the Commission on Higher Education (CHED) COVID Advisory no. 7 (Guidelines for the prevention, control, and mitigation of the spread of Coronavirus 2019

Corresponding author: Joshua Macapagal, DMD, MHPEd School of Dentistry

Centro Escolar University

San Miguel, Manila 1008, Philippines

Email: macapagal882005@gmail.com in Higher Education Institutions). ${ }^{4}$ The advisory stated that suspension of face-to-face classes shall be observed in areas under Enhanced Community Quarantine (ECQ), Modified 
Enhanced Community Quarantine (MECQ), and General Community Quarantine (GCQ). The Interagency Task Force (IATF) was tasked to issue directives on a particular city or province for this guideline to be lifted.

Distance education, online learning, and e-learning were prevalent during the pandemic. ${ }^{5}$ In this study, distance education referred to the delivery of education through distant physical separation between the health professions educator and the student. Online learning referred to access to learning resources on the internet, while e-learning referred to a system of learning through the use of electronic media. A paradigm shift was necessary for students to safely continue their education amidst the COVID-19 pandemic. ${ }^{6,7}$ The pandemic has affected the mode of instructional delivery, curriculum, educational outcomes, teaching methodologies, and the assessments administered to students.,8 Higher education institutions (HEIs) must take the initiative in creating an alternative model of implementation without compromising the attainment of learning outcomes. Assessing the students means the measurement, appraisal, and documentation of the development of students. ${ }^{9}$ Student assessment allows instructors to measure the effectiveness of teaching methods by associating the student's learning objectives with the student's performance. ${ }^{10}$ Students undergo a formative or summative assessment to ensure the attainment of learning outcomes in a specific course. By providing a way to determine the strengths and weaknesses of students, ${ }^{10,11}$ assessments can help instructors to respond by modifying their teaching methods. ${ }^{11}$ Over the years, online forms of student assessment have already been utilized in part. ${ }^{12}$ However, due to the transition of the mode of instruction to emergency remote learning, health professions educators needed to adapt to administering these assessments purely online. ${ }^{2,3}$ Challenges and limitations were encountered since there was a need to modify assessments, especially in the aspects of technical, pedagogical, resource support, and management. ${ }^{13}$ Understanding the challenges of online assessment is important for its success as a model for evaluating students' learning during the pandemic. ${ }^{14} \mathrm{~A}$ study of the challenges of assessment is beneficial for health professions educators and HEIs to understand which areas need to be improved to provide an appropriate environment for student assessment. ${ }^{11}$ This study aimed to explore the extent of knowledge available regarding the challenges of assessment in distance education of health professions during the 2020-2021 COVID-19 pandemic and to discuss a reflection in the Philippine setting.

\section{Health Professions Education in the Philippines}

Health professions is defined as a discipline composed of various types of professionals who provide a range of health care services in a wide variety of settings. ${ }^{15}$ The discipline includes health professionals working and studying in the health sciences. Health professionals include physicians, dentists, physical therapists, occupational therapists, radio- logic technologists, pharmacists, medical technologists, respiratory therapists, nutritionists, and dietitians. ${ }^{16-18}$ The uniqueness and diversity of different health-related courses are recognized in health professions. The Philippines has different undergraduate and post-graduate training programs associated with health professions. ${ }^{17}$ Health professionals who teach in their respective fields undergo formal training in health professions education. Health professions education is a discipline of knowledge that functions at the interface of health professions and education that aims to improve the preparation for teaching. ${ }^{19}$

\section{Assessment in Health Professions Education}

In the health professions, four major assessment methods are being implemented.The methods include written tests, oral examinations, performance tests, and clinical observational methods. ${ }^{20}$ Constructed-responses and selected-responses are prevalent in written forms in various health-related courses. Oral examination methods include demonstrations and subsequent probing of the learner's thinking or reasoning. ${ }^{15}$ An example of a performance-based assessment in a clinical setting is the Objective Structured Clinical Examination (OSCE). ${ }^{21}$ The OSCE is designed to measure and document the clinical skill of students in a health-related course. Observational assessment is a formative type of assessment, where the student is evaluated through the description of his or her clinical skill and the behaviors needed for patient care. ${ }^{22}$ Most health-related courses are patient-oriented, which resulted in the need for observational assessment. ${ }^{23,24}$ Additionally, outcomes-based education $(\mathrm{OBE})$ is a paradigm being utilized by Philippine Higher Education Institutions. ${ }^{25}$ The Commission on Higher Education (CHED) defines outcomes-based education as an approach that focuses on what is essential for all students to know, value, and be able to do to achieve a desired level of competence. Outcomes-based learning consists of three components. Firstly, traditional outcomes that express the curriculum's important aspects are what graduates must achieve in lectures. Secondly, transitional outcomes have something to do with an expected program level achievements, knowledge, and competencies. Lastly, transformational outcomes in the ideal OBE model require higher-order thinking skills, strong leadership, and problemsolving skills). ${ }^{26,27} \mathrm{OBE}$ should promote higher-order thinking skills among students. The promotion of higher-order skills in health professions can be assessed through assessment compatibility. ${ }^{15,16}$ In the attainment of course objectives, the compatibility of assessment is always considered to effectively align student progress with the course objectives.

\section{MATERIALS AND METHODS}

This study employed a rapid review ${ }^{28}$ method that uses structured and closely defined research questions to facilitate the timely synthesis of literature in the focus of challenges of assessment during the COVID-19 pandemic. Rapid 
reviews have been utilized because of time-constrained search and appraisal of articles published during the pandemic. ${ }^{28,29}$ Considering that the pandemic has been going on for one year during the writing of this report, published articles regarding assessment in the health professions were limited. The general research question was, "What are the challenges of assessment in the distance education of health professions?" The specific research question was, "What are the resources, learners' issues, technical issues of the learning management system, and methodological assessment issues that challenged the distance education assessment of health professions students during the COVID-19 pandemic?" The rationale for this study is the practicality of limiting the scope of the topics involved in the distance learning assessment. This study also employed an unsystematic search of literature in the Philippine context on challenges of assessment. The result of the unsystematic search and the knowledge of the authors regarding distance education in Philippine health professions are reflected on the results of the structured rapid review.

The primary investigator of this study performed an initial search of gray literature through Google Scholar before performing a systematic search of the literature. We searched the following databases: PubMed/Medline, Scopus, CINAHL, ERIC, Web of Science, and PsycINFO. Search terms were refined from literature review key terms and Medical Subject Headings (MeSH) (Appendix Table 1).

Inclusion criteria for the rapid review were the following: (1) articles written in English, (2) full-text availability, (3) original qualitative research, systematic reviews, or metaanalysis, (4) articles published in 2020 up to 2021, and (5) description of challenges in the assessment of health-related courses. Books, editorials, reviews, commentary articles, thesis, dissertations, unpublished materials, and letters to the editor were excluded. The reviewers discussed and deliberated on the final list of included studies.

The methodological quality of included systematic reviews was assessed using the "A Measurement Tool to Assess Systematic Reviews" (AMSTAR). ${ }^{30}$ Included qualitative research studies were assessed through criteria established by Mays and Pope: triangulation, respondent validation, clear exposition of data collection and analysis methods, researcher reflexivity, attention to negative cases, and fair dealing. ${ }^{31}$ Independent quality assessment was done by the authors, and any discrepancy in scores obtained by each study were discussed to obtain consensus.

\section{RESULTS AND DISCUSSION}

\section{Search for articles}

We identified 1,519 articles from database searching. A total of 546 duplicate articles were removed. Title and abstract screening of 973 articles resulted in exclusion of 932 articles. Assessment of 41 full-text reports excluded 32 articles that had irrelevant content and non-English

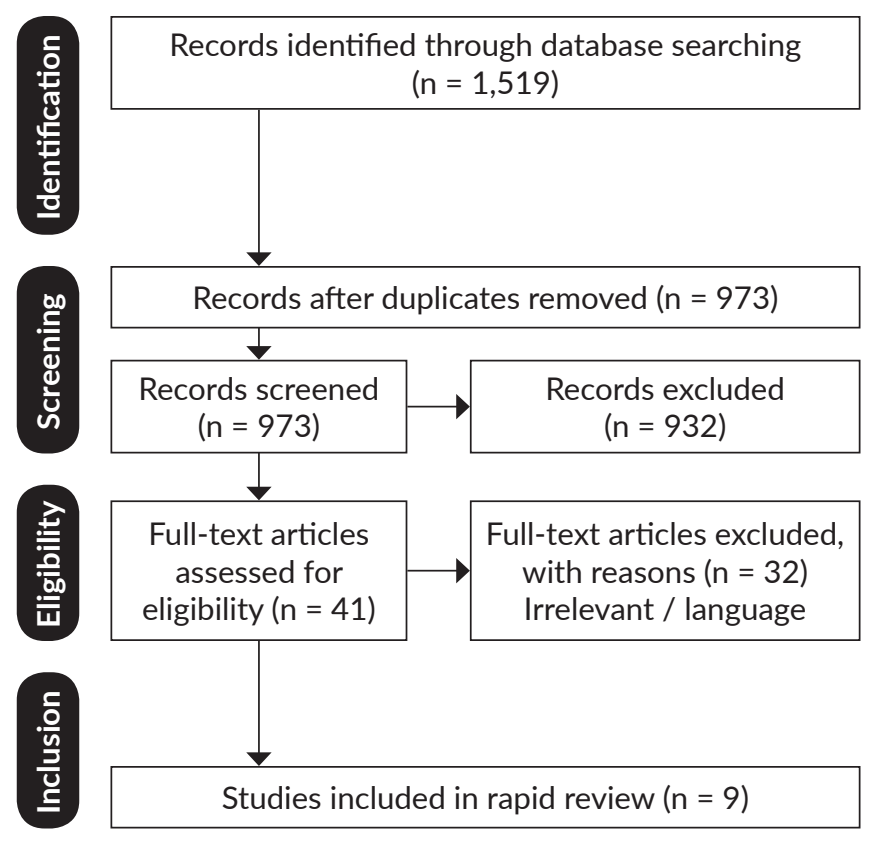

Figure 1. PRISMA flow chart of reviewed articles.

language. Nine articles were included in the final rapid review. Figure 1 shows a flowchart of the summary of the process of article inclusion.

We included six qualitative research articles and three review articles. Two included articles scored "high," while three articles scored "moderate," and four articles scored "poor" for quality assessment. The characteristics of the included articles as to purpose, issue of resources, learners' issues, technical issues, methodological issues of assessment and quality assessment are in Appendix Table 2.

\section{Challenges of Assessment}

Assessment in the health professions courses has been modified for emergency remote learning. Modification was important to achieve the curriculum objectives during the community quarantine. The major challenges of assessment in this study included issues regarding the resources, learner's issues, issues in the learning management system, and the methodological assessment issues.

\section{Resource issues}

Resources are sources of materials, staff, and financial means that enable an institution to function towards its goals and objectives. An effective distance education program is correlated to e-learning because it involves the usage of electronic media, a provision of two-way communication, and a base of operations. ${ }^{32,34}$ Information technology resources have always been a driving factor to implement an effective distance education program. The restriction of factors for the success of distance education has significance in the implementation of emergency remote learning in the Philippines. ${ }^{32}$ The 21 st century is the age of Information 


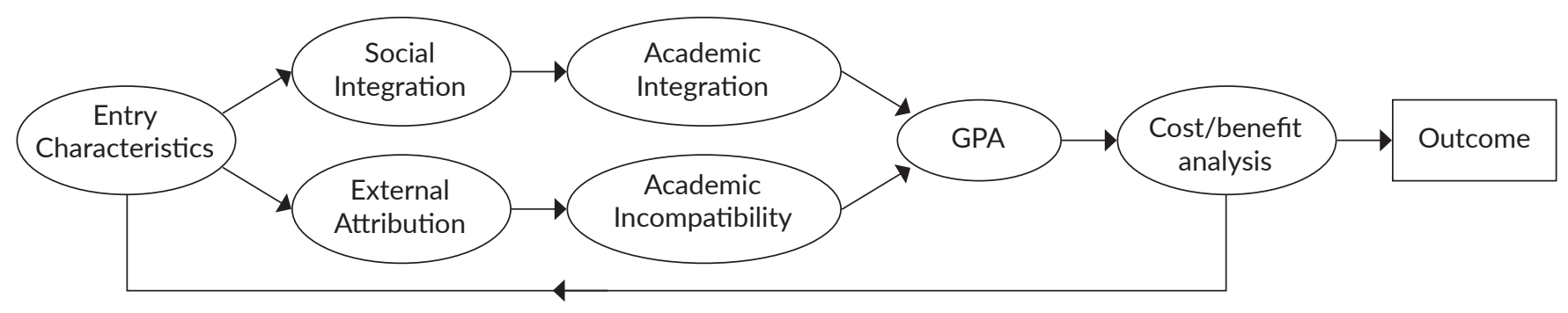

Figure 2. Kember's model of student's progress in distance education.

and Communication Technology (ICT). ${ }^{41}$ All over the globe, there is a trend to use ICT in the teaching and learning process. The teacher and learner must gain access to technology to improve learning outcomes. Educational reforms include the effective designing and implementation of ICT in the teaching-learning process, which is the key to success. It involves using computers, computer software, and other devices to convert, store, process, transmit and retrieve information; and include the services and applications.

Resource limitations serve as a physical barrier for instructors, learners, and educational institutions; this disables education during the COVID-19 pandemic. ${ }^{32-40}$ The absence of enabling resources for education has a strong influence on the implementation of curricular activities. ${ }^{39}$ The importance of resources is seen in each included article. The primary tools to enable assessment in distance education for teachers and students are hardware and software resources. ${ }^{33,38,39}$ The Philippines was not exempted from disabling circumstances during the COVID-19 pandemic. Limited hardware and communication capabilities are common among Filipinos. Desktop computers, laptops, cellphones, and tablets are the hardware that is capable of enabling distance learning. Some urban areas are still limited in hardware supply, while rural areas suffer the most. The availability of resources in the Philippines influences the implementation of distance education. Telecommunication was also disrupted inside urban centers. The Philippine internet speed and mobile data speed are still ranked below average when compared to other countries. ${ }^{42}$

The impact of typhoons amidst a devastating pandemic on students' learning is considerable. According to the Philippine Atmospheric Geophysical and Astronomical Services Administration (PAGASA), an average of twenty tropical cyclones hit the Philippines every year. The typhoon peak is from July through October, when nearly $70 \%$ of all typhoons develop. ${ }^{43}$ These typhoons are incredibly destructive and damaging. During this time, power supply and internet signal were also affected, thus making it more challenging to accomplish the assessments. ${ }^{44}$ Learning is difficult for students when the internet connection is problematic, especially in storm-affected areas. The COVID-19 pandemic has been a challenge for both teachers and students because of the closing of the academic year without a return to a face-to-face engagement.
The Philippine internet service providers include Philippine Long Distance Telephone Company (PLDT), Globe Telecom, Smart Telecommunications, Sky Broadband, Bayantel, Mozcom, Eastern Telecoms, Wi-Tribe, and Converge ICT. ${ }^{45}$ PLDT is the most widely used internet service provider in the Philippines because it allows other internet service providers to connect to the undersea cables running across the country. The Philippines placed 83rd in mobile data speed and 92nd in fixed broadband speed in February 2021 rankings (Speedtest Global Index), despite improvements announced by the Department of Information and Communications Technology. ${ }^{42}$ Around 50 million residents in the rural region have limited access to the internet. Among the 6.5 million students surveyed by the DepEd, 1.3 million students used public rental computers for distance learning, while 2.8 million students had no access to distance education. The Commission on Higher Education (CHED) announced 3.5 million tertiary level students needed resources for distance learning. ${ }^{46}$ These may significantly affect the internet access of students from health-related courses in the tertiary level of education.

\section{Learner Issues}

Every aspect that can influence the performance of the students in the academic institutions can be assessed..$^{33}$ Health professions educators can know the capacity of a student in health professions through appropriate assessment measures. The aspects that influence a student are identified by previous literature.

Kember's model of student's progress in distance education recognizes four concepts that are important for students undergoing remote learning, and may be applied to health-related courses. ${ }^{47}$ The four concepts include social integration, academic integration, external attribution, and academic incompatibility (Figure 2). This model was articulated in all the included articles.

Social integration has always been considered as one of the determinants in successfully completing a tertiary education course. ${ }^{37}$ Influential factors in social integration are a positive relationship with peers and involvement in extracurricular activities..$^{37-40,48}$ Social integration may be peer-to-peer or facilitator-to-student. The absence of any direct face-to-face social integration contributed to poor mental status of the students. ${ }^{32}$ The implementation of strict 
community quarantine protocols in the Philippines prevented physical interaction and face-to-face social activities. CHED advisory no. 7 prohibited all extracurricular activities that may require social gathering and mass activities. ${ }^{4}$ Online communication with peers is played a large role in social integration in the absence of extracurricular activities. Students without communication with their peers may have had weaker social integration during the pandemic. Peer affiliation in the Philippines increases the level of mastery goals. Mastery goals are concerned with the enhancement of the student's competence in a discipline. The adoption of social achievement goals by a group of students increases the academic performance of students. ${ }^{38,40,49}$

Academic integration is the combination of cognitive, technical, and scholarly skills in the attainment of the educational level. ${ }^{37}$ The need to persist and be successful depends on the level of attainment of education. In the case of most health-related courses, clinical competence is related to academic integration. ${ }^{34-36}$ Most of the included articles mentioned issues concerning clinical competence. Persistence in the academic sense requires students to become academically integrated to fulfill objectives or requirements in their respective educational levels. ${ }^{39}$ The sudden modification of curricular materials for remote learning was a challenge to Philippine health professions educators because it required them to provide a curriculum that encourages students to become academically integrated during community lockdowns. ${ }^{32}$ Sudden adjustments to the curriculum also affected the student's academic life. The student's usual activities for the school have been modified that may have led to cultural and academic shock. ${ }^{32-40}$ The sudden changes halted some operations by private and public institutions. During the start of the pandemic, a total of 180 countries announced the closure of some of their educational institutions, making the cultural and academic shock prominent in the world..$^{50}$ Closure of the schools was a big challenge towards assessment since students had no school to attend at all.

External attributions describe environmental or situational factors that ultimately influence a student's behavior during academic life. ${ }^{32,33}$ These are broad factors that may be overwhelming to quantify and describe. General categorical factors may include political, economic, social, and domestic factors. ${ }^{38}$ Filipino students were not exempted from experiencing external attributions. Political legislation and issues may contribute to the curriculum, which may affect learning. Economic status may contribute to the welfare of the students. Urban and rural communities in the Philippines have students below poverty status, which ultimately affects their academic studies. Social needs and demands are related to social integration. ${ }^{37}$ Social factors contribute through social experiences. Domestic factors are considered when a family is partially functional. Some families in the Philippines are broken. Children of broken families are most affected. The status of a broken family may lead to less support for the student's academic welfare and poor academic outcomes. The model dictates that external attributions are directly related to academic incompatibility. ${ }^{47}$ Academic incompatibility describes a student's inability to harmonize the attainment of academic requirements.

\section{Technical Issues of the Learning Management System}

Assessment for distance learning requires a platform that can be engaged by the health professions educator and the students. These platforms require a software application that enables synchronous and asynchronous communication on both ends. ${ }^{32}$ The Learning Management System (LMS) is a software system that allows health professions educators to facilitate education programs. Access to the LMS is through hardware (e.g., computers, mobile phones, and tablets). The LMS provides efficient learning environment in educational institutions where health professions educators administer the development of students through distance learning. ${ }^{32,33,39}$ Philippine colleges and universities are free to choose any LMS they prefer. However, it would depend on the price, applicability, and other logistic features of the LMS. Health science programs were also encouraged to implement LMS because of the pandemic. Using an LMS was not without challenges and limitations. The technical issues were: ${ }^{32-40}(1)$ accessibility to hardware, (2) user interface (UI) difficulty, and (3) Information Technology (IT) department resource management. Device access to the software has been a problem for some LMS, limited only to computers and not in mobile phones and tablets. The lack of the distribution of hardware in the rural region significantly influences the technical issue of access. ${ }^{34}$ Software that is accessible by most hardware are available but are limited. The UI has also been a problem for new users of the LMS. ${ }^{32,40}$ Students that are new to the LMS may find the user interface of LMS confusing and hard to navigate. The step-by-step process of creation of an internal account of the LMS and access to the institutional modules may cause problems if the user interface is difficult to navigate. The IT department of the educational institution must have strategically managed resources that will enable the LMS to function effectively. ${ }^{33,39}$ Important resource services that may relate to the Philippine setting include (1) role delegation, (2) technical support, (3) cybersecurity, and (4) hardware maintenance. Roles within the LMS must be clear to set limits on user access. Administrative roles and instructor roles must be established by the IT department for the LMS to discriminate functionality. If the LMS has technical difficulty with role delegation, then the whole system may not function towards the school's objectives. ${ }^{32,40,51}$ Technical support must always be accessible on the part of the IT department. Software and hardware technical issues may arise at any point in time during the performance of the LMS. The inaccessibility of the technical support may result in a delay of instructions to the students. Cybersecurity may also affect the implementation of the LMS. The intrusion of a malicious code or program in the LMS software 
application may also result in the delay of the functionality of the LMS. Unauthorized access of non-administrative personnel may also be possible if cybersecurity is absent. Appropriate measures of the LMS must be implemented to safeguard classified information of the educational institution. Proper hardware maintenance must always be considered for the LMS. The hardware that enables the LMS must be functional with no limited capabilities.

\section{Methodological Assessment Issues}

\section{Credibility and Monitoring of Assessment}

Since assessments are delivered online, the usual setup wherein instructors can facilitate and observe the class during the course of examination is limited. As a result, students cannot be monitored, especially if the online assessment is delivered asynchronously. ${ }^{32}$ Students can access the particular assessment at their own pace during the time allotment given by the instructor. Equivalent to a take-home or open-book test, the reliability of a non-proctored online assessment is unclear. ${ }^{33,38,52}$ The method poses a problem since students can check their answers using textbooks or other resource materials.

The actions of the students are evident with summative assessments, which incorporate selected-response and constructed-response types of examination. In a study by Rowe, ${ }^{53}$ he enumerated three major problems that involve cheating in online assessment. The first problem is getting the assessment answers in advance. Some online assessments can be accessed by students at their own pace. If the same sets of assessments are given to all students, students who have answered the examination earlier can supply the answers to other students who will take the exam at a later time. The second problem is the unfair retaking of assessments. Students can make up excuses such as unanticipated loss of internet connection, power interruption, crashing of the internet server, or even the use of the LMS. The instructors may allow the students to retake the assessments due to the excuses given by the students. The last problem is unauthorized support or collaboration between students during the assessment. ${ }^{32,37,53}$ Students can hire other individuals to take the assessment for them. ${ }^{53}$ These problems can affect the credibility of the assessments, particularly on the adequacy of interpretations of its results. There are measures that can be implemented. Even if measures are implemented to prevent the occurrence of these problems, it is still advisable for facilitators to be cautious in creating online assessments. The instructor must always consider the problems that might occur with the credibility and monitoring of assessments.

\section{Skills-based Assessment}

Most health professions programs require skills development and demonstration of clinical competencies. ${ }^{36}$ At the same time, instructors have to assess the students based on attainment of skills required to be competent health professionals. Historically, direct face-to-face skills-based assessment has always been the gold standard in assessing students in health-related courses. ${ }^{32-40}$ Due to community lockdowns, face-to-face classes, including skills-based assessment, were prohibited to prevent transmission of the SARS-CoV-2 virus. There is questionable ability to assess course objectives due to the absence of a direct face-toface skills-based assessment. Some of the included studies suggested the implementation of blended learning programs with modified skills-based assessment. Blended learning is an approach to education that utilizes both online and traditional face-to-face learning. ${ }^{54}$ It reduces other barriers for students, particularly around accessibility and flexibility in the context of health profession courses. ${ }^{55}$ It is important to consider blended learning for skill development, as a post-COVID approach, especially for health professions. Assessment of skills-based activities as part of blended learning compared to fully remote learning has increased pedagogical value because of the presence of clinical learning experience. ${ }^{56}$ Both absence of skills-based assessment in the Philippine setting and insufficient human resource in the health sector has resulted in decreased access to health services in the country. While some urban areas in the country have access to health services, the rural regions of the country have depleted human resources. The lack of direct face-to-face skillsbased assessment in the Philippines may delay producing competent health care professionals.

\section{CONCLUSION}

Review of published literature during the COVID-19 pandemic shows the challenges in assessment for distance education in the health professions. Although distance education provides a safer alternative for the delivery of assessment during the pandemic, it lacks direct evaluation of skills and appraisal of clinical competency for health courses with patient interaction. We identified local issues that were relatable to the international context, such as lack of resources, lack of technical support for the LMS, and absence of faceto-face skills-based assessment.

\section{Recommendations}

This rapid review may not have identified all the literature published on the challenges of assessment due to time constraints. Further investigation through a systematic review may provide comprehensive information about the challenges of assessment.

\section{Statement of Authorship}

All authors participated in the data collection and analysis and approved the final version submitted.

\section{Authors Declaration}

All authors declared no conflicts of interest. 


\section{Funding Source}

No funding support.

\section{REFERENCES}

1. Hou L, Mehta SD, Christian E, Joyce B, Olufunmilayo L, Anorlu R, et al. Impact of the COVID-19 pandemic on global health research training and education. J Glob Health. 2020; 10(2):020366. doi: 10.7189/jogh.10.020366

2. Gordon M, Patricio M, Horne L, Muston A, Alston SR, Pammi $\mathrm{M}$, et al. Developments in medical education in response to the COVID-19 pandemic: a rapid BEME systematic review: BEME Guide No. 63. Med Teach. 2020; 42(11):1202-15. doi: 10.1080/0142159X.2020.1807484

3. Elzainy A, El Sadik A, Al Abdulmonem W. Experience of e-learning and online assessment during the COVID-19 pandemic at the College of Medicine, Qassim University. J Taibah Univ Med Sci. 2020; 15(6):456-62. doi: 10.1016/j.jtumed.2020.09.005

4. Commission on Higher Education. Guidelines for the Prevention, Control and Mitigation of the Spread of Coronavirus Disease 2019 (COVID-19) in Higher Education Institutions (HEIs) [Internet]. 2020 [cited 2021 Feb]. Available from: https://ched.gov.ph/wpcontent/uploads/CHED-ADVISORY-7-final.pdf

5. Qandil A, Abdel-Halim H. Distance e-Learning is closer than everybody thought: a pharmacy education perspective. Health Prof Educ. 2020; 6(3):301-3. doi.: 10.1016/j.hpe.2020.05.004

6. Ithwanay A, Ahsan F, Oliveri F, Goud HK, Mehkari Z, Mohammed L, et al. Medical education, pre- and post-pandemic era: a review article. Cureus. 2020; 12(10):e10775. doi: 10.7759/cureus.10775

7. Alsoufi A, Alsuyihili A, Msherghi A, Elhadi A, Atiyah H, Ashini A, et al. Impact of the COVID-19 pandemic on medical education: Medical students' knowledge, attitudes, and practices regarding electronic learning. PLoS One. 2020; 15(11):e0242905. doi: 10.1371/ journal.pone. 0242905

8. Sandhu P, de Wolf M. The impact of COVID-19 on the undergraduate medical curriculum. Med Educ Online. 2020; 25(1):1764740. doi: 10.1080/10872981.2020.1764740

9. Brits H, Bezuidenhout J, van der Merwe LJ, Joubert G. Students' voices: assessment in undergraduate clinical medicine. Pan Afr Med J. 2020; 36:130. doi: 10.11604/pamj.2020.36.130.22168

10. Hodges BD. Performance-based assessment in the 21st century: when the examiner is a machine. Perspect Med Educ. 2021; 10(1):3-5. doi:10.1007/s40037-020-00647-4

11. Schuwirth LWT, Durning SJ, King SM. Assessment of clinical reasoning: three evolutions of thought. Diagn. 2020; 7(3):191-6. doi: 10.1515/dx-2019-0096

12. Lima KR, das Neves BS, Ramires CC, dos Santos Soares M, Martini VA, Lopez LF, et al. Student assessment of online tools to foster engagement during the COVID-19 quarantine. Adv Physiol Educ. 2020; 44(4):679-83. doi: 10.1152/advan.00131.2020

13. Kogan M, Klein SE, Hannon CP, Nolte MT. Orthopaedic education during the COVID-19 pandemic. J Am Acad Orthop Surg. 2020; 28(11):e456-e464. doi: 10.5435/JAAOS-D-20-00292

14. Theoret C, Ming X. Our education, our concerns: The impact on medical student education of COVID-19. Med Educ. 2020; 54(7): 591-2. doi: 10.1111/medu.14181

15. Yudkowsky R, Park YS, Downing SM. Assessment in Health Professions Education. 2nd edition. Routledge: New York. 2020.

16. Kahlke R, Eva K. Constructing critical thinking in health professional education. Perspect Med Educ. 2018; 7(3):156-65. doi: 10.1007/ s40037-018-0415-z

17. Dalanon J, Matsuka Y. Forecasting Interest in Health Professions Education Based on Relative Search Volume Trends from the Philippines. Health Prof Educ. 2020; 6(3):368-75. doi:10.1016/ j.hpe.2020.04.010

18. Tekian A, Harris I. Preparing health professions education leaders worldwide: A description of masters-level programs. Med Teach. 2012; 34(1):52-8. doi: 10.3109/0142159x.2011.599895
19. Sana EA. Teaching and Learning in the Health Sciences. The University of the Philippines Press. 2010

20. Downing SM. Yudkowsky R. Four Major Assessment Methods. In: Assessment in Health Professions Education. 2nd edition. Routledge: New York. 2020. pp. 5-8.

21. Khan KZ, Ramachandran S, Gaunt K, Pushkar P. The Objective Structured Clinical Examination (OSCE): AMEE Guide No. 81. Part I: an historical and theoretical perspective. Med Teach. 2013; 35(9):e1437-46. doi: 10.3109/0142159X.2013.818634

22. Ahmed K, Miskovic D, Darzi A, Athanasiou T, Hanna GB. Observational tools for assessment of procedural skills: a systematic review. Am J Surg. 2011; 202(4):469-80.e6. https://doi.org/10.1016/ j.amjsurg.2010.10.020

23. Newell S, Jordan Z. The patient experience of patient-centered communication with nurses in the hospital setting: a qualitative systematic review protocol. JBI Database System Rev Implement Rep. 2015; 13(1):76-87. doi: 10.11124/jbisrir-2015-1072

24. Constand MK, MacDermid JC, Dal Bello-Haas V, Law M. Scoping review of patient-centered care approaches in healthcare. BMC Health Serv Res. 2014; 14:271. doi: 10.1186/1472-6963-14-271

25. Commission on Higher Education. Policy-Standard to Enhance Quality Assurance (QA) in Philippine Higher Education through an Outcomes-based and Typology-based QA [Internet]. 2012 [cited $2021 \mathrm{Feb}$. Available from: https://ched.gov.ph/cmo-46-s-2012/

26. Jansen JD. Curriculum Reform in South Africa: a critical analysis of outcomes-based education. Camb J Educ. 1998; 28(3):321-31. doi: 10.1080/0305764980280305

27. Rosenberg ME. An outcomes-based approach across the medical education continuum. Trans Am Clin Climatol Assoc. 2018; 129: $325-40$.

28. Virginia Commonwealth University. Rapid Review Protocol [Internet]. 2018 [cited 2021 May]. Available from: https://guides.library.vcu. edu/rapidreview

29. Grant MJ, Booth A. A typology of reviews: an analysis of 14 review types and associated methodologies. Health Info Libr J. 2009; 26(2):91-108. doi:10.1111/j.1471-1842.2009.00848.x

30. Shea BJ, Grimshaw JM, Wells GA, Boers M, Andersson N, Hamel C, et al. Development of AMSTAR: a measurement tool to assess the methodological quality of systematic reviews. BioMed Central Med Res Methodol. 2007;7:10

31. Mays N, Pope C. Qualitative research in health care. Assessing quality in qualitative research. BMJ. 2000; 320(7226):50-2. doi: 10.1136/ bmj.320.7226.50

32. Baticulon RE, Sy JJ, Alberto NRI, Baron MBC, Mabulay REC, Rizada LGT, et al. Barriers to Online Learning in the Time of COVID-19: A National Survey of Medical Students in the Philippines. Med Sci Educ. 2021;1-12. doi: 10.1007/s40670-021-01231-z

33. Gaur U, Majumder MAA, Sa B, Sarkar S, Williams A, Singh K. Challenges and opportunities of preclinical medical education: COVID-19 crisis and beyond. SN Compr Clin Med. 2020;1-6. doi: 10.1007/s42399-020-00528-1

34. Wittayanakorn N, Nga VDW, Sobana M, Bahuri NFA, Baticulon RE. Impact of COVID-19 on neurosurgical training in Southeast Asia. World Neurosurg. 2020; 144:e164-e177. doi: 10.1016/j.wneu. 2020.08.073

35. Cunningham C, Moore Z, Connor TO, Patton D, Bux D, Nugent L. eHealth for neonatal nurse education despite COVID-19. J Neonatal Nurs. 2020. doi: 10.1016/j.jnn.2020.11.002

36. Iyer P, Aziz K, Ojcius DM. Impact of COVID-19 on dental education in the United States. J Dent Educ. 2020; 84(6):718-22. doi: 10.1002/ jdd.12163

37. Ng L, Seow KC, MacDonald L, Correia C, Reubenson A, Gardner $\mathrm{P}$, et al. eLearning in physical therapy: lessons learned from transitioning a professional education program to full elearning during the COVID-19 pandemic. Phys Ther. 2021. doi: 10.1093/ptj/pzab082

38. Alqurshi A. Investigating the impact of COVID-19 lockdown on pharmaceutical education in Saudi Arabia - A call for a remote teaching contingency strategy. Saudi Pharm J. 2020; 28(9):1075-83. doi: 10.1016/j.jsps.2020.07.008 
39. Rajab MH, Gazal AM, Alkattan K. Challenges to online medical education during the COVID-19 pandemic. Cureus. 2020; 12(7):e8966. doi: 10.7759/cureus.8966

40. Al-Balas M, Al-Balas HI, Jaber HM, Obeidat K, Al-Balas H, Aborajooh EA, et al. Distance learning in clinical medical education amid COVID-19 pandemic in Jordan: current situation, challenges, and perspectives. BMC Med Educ. 2020; 20(1):341. doi: 10.1186/ s12909-020-02257-4

41. Kereluik K, Mishra P, Fahnoe C, Terry L. What knowledge is of most worth. J Digit Learn Teach Educ. 2013; 29(4):127-40. doi: 10.1080/21532974.2013.10784716

42. Speedtest Global Index. Philippines February 2021 [Internet]. 2021 [cited $2021 \mathrm{Feb}$. Available from: https://www.speedtest.net/globalindex/philippines

43. United Nations Office for the Coordination of Humanitarian Affairs. Philippines: Typhoon Ambo (Vongfong) - Information Bulletin [Internet]. 2020 [cited $2021 \mathrm{Feb}$ ]. Available from: https://reliefweb. int/report/philippines/philippines-typhoon-ambo-vongfonginformation-bulletin

44. Rappler. Bicol students struggle with distance learning after Super Typhoon Rolly devastates region [Internet]. 2020 [cited 2021 Feb]. Available from: https://www.rappler.com/moveph/bicol-studentsstruggle-distance-learning-typhoon-rolly-devastates-region

45. Salac RA, Kim YS. A study on the internet connectivity in the Philippines. Asia Pac J Bus Rev. 2016; 1(1):67-88. doi: 10.20522/ APJBR.2016.1.1.67

46. Joaquin JJ, Biana HT, Dacela MA. The Philippine higher education sector in the time of COVID-19. Front Educ. 2020; 5:576371. doi: 10.3389/feduc.2020.576371

47. Woodley A, de Lange P, Tanewski G. Student progress in distance education: Kember's model re-visited. Open Learn J Open Distance e-Learn. 2001; 16(2), 113-131. https://doi.org/ 10.1080/02680510123105
48. Lakhal S, Mukamurera J, Bédard M, Heilporn G, Chauret M. Features fostering academic and social integration in blended synchronous courses in graduate programs. Int $\mathrm{J}$ Educ Technol High Educ. 2020;17(5). doi: 10.1186/s41239-020-0180-z

49. Bernardo AB, Ismail R. Social perceptions of achieving students and achievement goals of students in Malaysia and the Philippines. Soc Psy Educ. 2010;13,385-407. doi: 10.1007/s11218-010-9118-y

50. British Broadcasting Corporation. Coronavirus: What measures are countries taking to stop it? [Internet].2020 [cited 2021 May]. Available from: https://www.bbc.com/news/world-51737226

51. Kurata YB, Bano RMLP, Marcelo MCT. Effectiveness of learning management system application in the learnability of tertiary students in an undergraduate engineering program in the Philippines. Adv Hum Factors Train Educ Learn Sci. 2017; 596:142-51. doi: 10.1007/978-3-319-60018-5_15

52. Arnold, S.D. Assessing student learning online. In Digital Systems for Open Access to Formal and Informal Learning. Springer, Cham. 2014: 83-100

53. Rowe NC. Cheating in online student assessment: beyond plagiarism. In Online J Distance Learn Adm. 2004;7(2). https://www.westga. edu/ distance/ojdla/summer72/rowe72.html

54. Biluc AM, Goodyear P, Ellis RA. Research focus and methodological choices in studies into students' experiences of blended learning in higher education. Int High Educ. 2007; 10(4):231-44. doi: 10.1016/ j.iheduc.2007.08.001

55. Jowsey T, Foster G, Cooper-Ioelu P, Jacobs S. Blended learning via distance in pre-registration nursing education: A scoping review. Nurse Educ Prac. 2020;596. doi: 10.1016/j.nepr.2020.102775

56. McCutcheon K, O'Halloran P, Lohan M. Online learning versus blended learning of clinical supervisee skills with pre-registration nursing students: A randomised controlled trial. Int J Nurs Stud. 2018; 82:30-9. doi: 10.1016/j.ijnurstu.2018.02.005

\section{APPENDICES}

Appendix Table 1. Search strategy for literature review

\section{Key terms}

"Assessment Issues", "Assessment Challenges", "Distance Education",

"Online Learning", "Pandemic",

"COVID-19", "Health Professions

Education", " Health Professions".

\section{$\mathrm{MeSH}$}

"Health Occupations", "Health Professions", "Health Education", "Health Educators", "Distance Education", "Distance Learning", "Online Learning", "Online Education", "Medical Education", "Educational Assessment".

\section{Refined Search Terms}

"challenges of assessment or issues of assessment", "online learning assessment", "distance learning assessment", "challenges of online-learning assessment or challenges of distance learning assessment", "health courses assessment", "health professions education assessment", "online learning health student assessment or distance learning health student assessment", and "distance learning assessment COVID-19". 
Appendix Table 2. Characteristics of the included articles

\begin{tabular}{|c|c|c|c|c|c|c|}
\hline Author & Purpose & $\begin{array}{c}\text { Issue of } \\
\text { Resources }\end{array}$ & Learners' Issue & $\begin{array}{l}\text { Technical issue } \\
\text { of Learning } \\
\text { Management } \\
\text { System }\end{array}$ & $\begin{array}{l}\text { Methodological } \\
\text { issue of } \\
\text { assessment }\end{array}$ & $\begin{array}{l}\text { Quality } \\
\text { Assess- } \\
\text { ment }\end{array}$ \\
\hline $\begin{array}{l}\text { Baticulon et al. } \\
(2021)^{32}\end{array}$ & $\begin{array}{l}\text { Identify barriers to online learning } \\
\text { from the perspective of medical } \\
\text { students in a developing country }\end{array}$ & $\begin{array}{l}\text { Lack of hardware } \\
\text { devices, internet } \\
\text { connection, } \\
\text { lack of technical } \\
\text { support }\end{array}$ & $\begin{array}{l}\text { Social inter- } \\
\text { action, mental } \\
\text { health diffi- } \\
\text { culties, physical } \\
\text { health concerns, } \\
\text { learning style } \\
\text { adjustments }\end{array}$ & $\begin{array}{l}\text { Platform } \\
\text { incompatibility } \\
\text { to hardware }\end{array}$ & $\begin{array}{l}\text { Gaps in knowledge } \\
\text { and skills from } \\
\text { current teaching } \\
\text { methods }\end{array}$ & High \\
\hline $\begin{array}{l}\text { Gaur et al. } \\
(2020)^{33}\end{array}$ & $\begin{array}{l}\text { Examine the challenges and } \\
\text { opportunities faced by medical } \\
\text { schools in implementing remote } \\
\text { learning for basic science teaching } \\
\text { in response to the COVID-19 crisis. }\end{array}$ & $\begin{array}{l}\text { Lack of hardware } \\
\text { devices, } \\
\text { software, } \\
\text { and internet } \\
\text { connection }\end{array}$ & $\begin{array}{l}\text { Social } \\
\text { interaction }\end{array}$ & $\begin{array}{l}\text { LMS compatibility } \\
\text { to online } \\
\text { platforms, lack of } \\
\text { technical support }\end{array}$ & $\begin{array}{l}\text { Assessment } \\
\text { validity, } \\
\text { asynchronous } \\
\text { assessment issues }\end{array}$ & Moderate \\
\hline $\begin{array}{l}\text { Wittayanakorn } \\
\text { et al. }(2020)^{34}\end{array}$ & $\begin{array}{l}\text { Describe the impact of the } \\
\text { COVID-19 pandemic on } \\
\text { neurosurgical training in Indonesia, } \\
\text { Malaysia, Philippines, Singapore, } \\
\text { and Thailand }\end{array}$ & $\begin{array}{l}\text { Lack of hardware } \\
\text { devices, internet } \\
\text { connection }\end{array}$ & $\begin{array}{l}\text { Clinical } \\
\text { competency }\end{array}$ & Absence of LMS & $\begin{array}{l}\text { Skills-based } \\
\text { Assessment, } \\
\text { Clinical } \\
\text { competency }\end{array}$ & Poor \\
\hline $\begin{array}{l}\text { Cunningham } \\
\text { et al. }(2020)^{35}\end{array}$ & $\begin{array}{l}\text { Assess the volunteering of } \\
\text { undergraduate health students } \\
\text { and interns in the Ministry of } \\
\text { Health (MOH) services in the } \\
\text { Kingdom of Saudi Arabia (KSA) } \\
\text { during the COVID-19 pandemic, its } \\
\text { motivational factors, and barriers, } \\
\text { as well as their risk perception of } \\
\text { COVID-19 }\end{array}$ & $\begin{array}{l}\text { Lack of hardware } \\
\text { devices, internet } \\
\text { connection }\end{array}$ & $\begin{array}{l}\text { Clinical } \\
\text { competency }\end{array}$ & $\begin{array}{l}\text { Competency in } \\
\text { Information and } \\
\text { Communication } \\
\text { Technology (ICT) }\end{array}$ & $\begin{array}{l}\text { Critical appraisal } \\
\text { skills assessment, } \\
\text { Skills-based } \\
\text { Assessment }\end{array}$ & Poor \\
\hline $\begin{array}{l}\text { lyer et al. } \\
(2020)^{36}\end{array}$ & $\begin{array}{l}\text { Discuss the challenges that we } \\
\text { face currently and offers some } \\
\text { simple strategies to bridge the gaps } \\
\text { in dental education to overcome } \\
\text { this emergency }\end{array}$ & $\begin{array}{l}\text { Internet } \\
\text { connection }\end{array}$ & $\begin{array}{l}\text { Clinical } \\
\text { competency }\end{array}$ & $\begin{array}{l}\text { LMS compatibility } \\
\text { to online } \\
\text { platforms }\end{array}$ & $\begin{array}{l}\text { Skills-based } \\
\text { Assessment, } \\
\text { Objective } \\
\text { Structured Clinical } \\
\text { Exam (OSCE) }\end{array}$ & Poor \\
\hline $\begin{array}{l}\mathrm{Ng} \text { et al. } \\
(2021)^{37}\end{array}$ & $\begin{array}{l}\text { Explore the perspectives } \\
\text { of students enrolled in one } \\
\text { undergraduate physical therapist } \\
\text { education program in Australia } \\
\text { about their early experience } \\
\text { with full eLearning during the } \\
\text { COVID-19 pandemic }\end{array}$ & $\begin{array}{l}\text { Lack of hardware } \\
\text { devices, internet } \\
\text { connection }\end{array}$ & $\begin{array}{l}\text { Social inter- } \\
\text { action, mental } \\
\text { health issues, } \\
\text { learning style } \\
\text { adjustments, } \\
\text { clinical } \\
\text { competency }\end{array}$ & Absence of LMS & $\begin{array}{l}\text { Skills-based } \\
\text { Assessment }\end{array}$ & Moderate \\
\hline $\begin{array}{l}\text { Alqurshi } \\
(2020)^{38}\end{array}$ & $\begin{array}{l}\text { Investigate the effect emergency } \\
\text { remote teaching has had on } \\
\text { pharmacy education in Saudi } \\
\text { Arabia, and to provide recommen- } \\
\text { dations that may help set in place } \\
\text { a contingency strategy }\end{array}$ & $\begin{array}{l}\text { Lack of hardware } \\
\text { devices, } \\
\text { software, } \\
\text { and internet } \\
\text { connection }\end{array}$ & $\begin{array}{l}\text { Social } \\
\text { interaction }\end{array}$ & $\begin{array}{l}\text { LMS compatibility } \\
\text { to online } \\
\text { platforms }\end{array}$ & $\begin{array}{l}\text { Assessment } \\
\text { validity, } \\
\text { asynchronous } \\
\text { assessment issues }\end{array}$ & High \\
\hline $\begin{array}{l}\text { Rajab et al. } \\
(2020)^{39}\end{array}$ & $\begin{array}{l}\text { Analyze the impact of the } \\
\text { COVID-19 pandemic on online } \\
\text { education at the College of } \\
\text { Medicine (COM) of Alfaisal } \\
\text { University in Riyadh, Saudi Arabia }\end{array}$ & $\begin{array}{l}\text { Lack of hardware } \\
\text { devices, } \\
\text { software, } \\
\text { and internet } \\
\text { connection }\end{array}$ & $\begin{array}{l}\text { Social } \\
\text { interaction, } \\
\text { clinical } \\
\text { competency }\end{array}$ & $\begin{array}{l}\text { LMS compatibility } \\
\text { to online } \\
\text { platforms, lack of } \\
\text { technical support }\end{array}$ & $\begin{array}{l}\text { Gaps in knowledge } \\
\text { and skills from } \\
\text { current teaching } \\
\text { methods, lack } \\
\text { of experience in } \\
\text { online assessment }\end{array}$ & Moderate \\
\hline $\begin{array}{l}\text { Al-Balas et al. } \\
(2020)^{40}\end{array}$ & $\begin{array}{l}\text { Explore the situation of distance } \\
\text { E-learning among medical students } \\
\text { during their clinical years and } \\
\text { to identify possible challenges, } \\
\text { limitations, satisfaction as well } \\
\text { as perspectives for this approach } \\
\text { to learning }\end{array}$ & $\begin{array}{l}\text { Lack of hardware } \\
\text { devices, internet } \\
\text { connection }\end{array}$ & $\begin{array}{l}\text { Social } \\
\text { interaction, } \\
\text { clinical } \\
\text { competency }\end{array}$ & $\begin{array}{l}\text { Competency in } \\
\text { Information and } \\
\text { Communication } \\
\text { Technology (ICT) }\end{array}$ & $\begin{array}{l}\text { Gaps in knowledge } \\
\text { and skills from } \\
\text { current teaching } \\
\text { methods }\end{array}$ & Poor \\
\hline
\end{tabular}

